\section{МЕХАНІЗМ АНТИКРИЗОВОГО УПРАВЛІННЯ ПОРТОМ НА ОСНОВІ ВПРОВАДЖЕННЯ ДЕРЖАВНО-ПРИВАТНОГО ПАРТНЕРСТВА}

\author{
MECHANISM OF ANTI-CRISIS \\ MANAGEMENT OF PORT ON THE \\ BASIS OF IMPLEMENTATION OF \\ PUBLIC-PRIVATE PARTNERSHIP
}

\author{
ОЧЕРЕДЬКО О. О., \\ кандидат економічних наук, \\ старший викладач, \\ НОСОВСЬКА О.Б., \\ кандидат технічних наук, доцент з \\ вищої математики, доцент \\ кафедри Природничо-наукових і \\ гуманітарних дисциплін, \\ МУНТЯН О. Л., \\ магістрант, Азовський морський \\ інститут Національного \\ університету, «Одеська морська \\ академія»
}

\author{
OCHEREDKO O., \\ $\mathrm{PhD}$ in Economics, Senior Lecturer, \\ NOSOVSKA O., \\ PhD in Technical Sciences, \\ Associate Professor, Associate \\ Professor of the Department of \\ Natural Science and Humanitarian \\ Disciplines, \\ MUNTIAN O. \\ Master's student of the Department \\ of Management and \\ Entrepreneurship in Maritime \\ Transport, Azov Maritime Institute \\ National University "Odessa \\ Maritime Academy"
}

У статті проаналізовано механізм антикризового управління портом на основі впровадження державно-приватного партнерства. У теперішніх умовах пандемії існує необхідність постійної підтримки та вдосконалення механізму управління підприємствами морського та річкового транспорту. Від застосування певного механізму залежить розвиток порту, морегосподарського комплексу та країни.

Ключові слова: порт, механізм антикризового управління, державно-приватне партнерство.

В статье проанализирован механизм антикризисного управления портом на основе внедрения государственно-частного партнерства. В нынешних условиях пандемии существует необходимость поддержки и совершенствования механизма управления предприятиями морского и речного транспорта. От использования определенного механизма зависит развитие порта, морехозяйственного комплекса и страны.

Ключевые слова: порт, механизм антикризисного управления, государственно-частное партнерство.

In this article, we analyzed the mechanism of anti-crisis port management based on the introduction of public-private partnership. In the current conditions of the pandemic, there is a need to support and improve the management mechanism of maritime and river transport enterprises. The development of the port, the maritime complex and the country depends on the application of a certain mechanism.

Keywords: port, anti-crisis management mechanism, public-private partnership.

Постановка проблеми. Управління підприємствами морського та річкового транспорту засноване на обліку антикризових засадах та закономірностях постійної оптимізації діяльності порту в системі міжнародних ринкових обмежень. Проблема чіткої та ефективної організації роботи механізму антикризового управління виникає із 
формуванням конкурентних технологій та доцільного їх використання в умовах обмеженості ресурсів, попиту та пандемії.

Аналіз останніх досліджень $і$ публікацій. Теоретичним і практичним аспектам державно-приватного партнерства займалися наступні науковці: Н. Безбах, Г. Ходжем, Є. Васильєв, К. Грівом, А. Куїмом, Р. Кучер, М. Солодаренко, Д. Дж. Делмоном, Ю. Пащенко, Г. Фішбейном, К. Лерніченко. Р. Бейном, Б. Винницький, П. Сегварі та iH.

Метою статті $€$ вдосконалення механізму антикризового управління Державного підприємства «Бердянський морський торговельни'ч порт» на основі впровадження державно-приватного партнерства.

Виклад основного матеріалу дослідження. Основою механізму державно-приватного партнерства $€$ процес позабюджетного інвестування в різні типи інфраструктури або об'єкти виробничої i невиробничої сфери. На сучасному етапі найкраще себе зарекомендував такий механізм як управлінський облік. Управлінський облік, крім усього вищесказаного, на підприємстві виконує функцію постійно діючої ревізії, оскільки постійно контролює всі господарські операції.

Відповідні моделі портів для кожної країни слід обирати та оцінювати за тим, наскільки вони досягають передбачуваної цілі. Найчастішим прикладом $€$ контейнерні термінали, якими зазвичай керують приватні спеціалісти. Постійна тенденція до приватизації портів ускладнює характеристику порту лише за однією моделлю; особливо за моделлю інструментального порту, яка $€$ переходом між моделлю державної служби та моделлю орендодавця.

Щоб більш чітко визначити участь як приватного, так і державного секторів, потрібно більш точний опис їхніх ролей та функцій у діяльності кожного порту (власність порту, операції, управління портом).

У прийнятті моделі домінують кілька внутрішніх (національна економіка, питання управління) та зовнішніх (морські суб'єкти, внутрішні характеристики.) параметрів та обмежень:

Порт керується єдиною інтегрованою організацією, і прийняття антикризових рішень перебуває в руках одного органу влади, що сприяє згуртованості та логіці прийняття рішень, що веде порт до зростання. Однак порт громадського обслуговування страждає від відсутності внутрішньої конкуренції, що, можливо, призводить до неефективності діяльності адміністрації порту та відсутність застосування інновацій. Порти громадського обслуговування були домінуючою моделлю наприкінці 80-х років.

Основною перевагою порту $\epsilon$ те, що всі інвестиції в порт керуються державою, i тому вся портова інфраструктура та обладнання для розвантаження ретельно обираються координація між усіма сторонами.

У цій моделі приватний сектор залучений до обробки вантажів та організації роботи порту, без фактично володіння будь-яким із основних об'єктів порту, що може призвести до конфлікту та обмежити майбутню діяльність.

Розширення підприємства. Наразі модель Tool Port широко використовується в багатьох країнах як спосіб передачі деякі державні завдання приватному сектору. 
Модель Landlord Port має ряд переваг, тому вона є найвідомішою моделлю сьогодення. Обов'язки щодо залучення інвестицій у розвиток порту чітко розподілені між урядом і приватним сектором, що дозволяє приватним інвесторам ефективно задовольняти попит клієнтів та держава збалансовує свої інвестиції та обмежити розсіювання ресурсів у портах.

Однак, оскільки приватний сектор відіграє роль в управлінні портом, він може чинити тиск на керівництво порту та збільшити інфраструктуру та землю 3 метою збільшення прибутку та/або підвищення конкурентоспроможності; тому між обома партнерами може виникнути напруга.

Як власники приватних портів обслуговування, приватні інвестори можуть активно інвестувати в будівництво нових морських портів та розробку політики щодо морських портових зборів у відповідний спосіб, без державного втручання. Однак це може призвести до монополістичної поведінки та перешкоджати уряду здійснювати економічну політику в портовій діяльності або контролювати стратегічні питання, які можуть спричинити ризики для держави.

Сьогодні модель приватного сервісного порту загалом обмежується конкретними випадками, доручаючи приватному сектору деяке управління функції (регулюючі, портові операції, планування, організація тощо).

Державно-приватні партнерства відрізняються за формами та умовами залежно від контексту, параметрів, проєктів обмеження, ступінь необхідного внеску від кожного партнера, рівень передачі ризику та інвестицій, та бажані результати. Тому різні види контрактів державно-приватного партнерства можливі, тобто це може бути:

1. Контракт на управління. Орган, що присуджує та наймає підрядника для управління рядом діяльність на відносно короткий період (3-5 років). Контракти на управління, як правило створюються для конкретних та орієнтованих на вхід, а не на вихід. Зазвичай угоди на експлуатацію та технічне обслуговування мають більше вимог до продуктивності - орієнтований на вихід.

2. Договір лізингу: приватний оператор відповідає за експлуатацію та обслуговування комунального підприємства, але не для фінансування інвестицій.

3. Реабілітація, експлуатація та передача: приватна сторона відповідає за відновлення, оновлення або розширення існуючих активів.

4. Реконструкція, оренда/оренда та передача: приватний спонсор відновлює існуючий об'єкт на власний ризик орендує або орендує об'єкт у уряду, потім експлуатує та обслуговує об'єкт на власний ризик протягом терміну дії договору.

5. Торговець: приватний інвестор будує новий об'єкт на лібералізованому ринку, на якому уряд не надає жодних гарантій доходів чи платежів. Приватний забудовник припускає будівельний, операційний та ринковий ризик для проєкту.

6. Приватний розробник створює доповнення до існуючого об'єкта або добудовує частково збудований об'єкт і відновлює наявні активи, а потім експлуатує і утримує об'єкт на власний ризик протягом терміну дії договору.

7. Будуйте, експлуатуйте та передавайте: приватний спонсор будує новий об'єкт на власний ризик, володіє та експлуатує об'єкт на 
власний ризик, а потім передає його уряду в кінці терміну термін дії договору.

8. Побудуйте власну експлуатацію та передачу: приватний інвестор будує новий об'єкт на власний ризик, володіє та експлуатує об'єкт на власний ризик, а потім передає його державі наприкінці терміну дії договору.

9. Будувати, орендувати та володіти: приватний спонсор будує новий об'єкт, переважно на свій страх і ризик, передає у власність державі, орендує об'єкт у держави та експлуатує він на свій страх і ризик, потім отримує повне право власності на об'єкт після закінчення концесійного періоду.

10. Будуйте, володійте та експлуатуйте: приватний спонсор будує новий об'єкт на власний ризик, а потім володіє і керує ним на власний ризик.

11. Часткова приватизація: вона вимагає постійної, активної ролі уряду, який зберігає відповідальність за виконання функції при делегуванні фактичної виробничої діяльності приватним особам сектору.

12. Приватизація: всі або майже всі інтереси уряду в комунальному активі або секторі передаються приватному сектору. Повна приватизація часто вважається більш остаточною формою участі приватного сектора в комунальному підприємстві, ніж концесія.

Морський транспорт $€$ одним із найстаріших і найважливіших видів транспортування вантажів, і це продовжує відігравати важливу роль у національному та глобальному економічному зростанні та міцних відносинах між ними та територією. Оскільки потреба в торгівлі та переміщенні товарів зростає, ефективність морської діяльності транспорту стає більш важливим.

Після Другої світової війни міжнародна торгівля товарами зросла з 58 мільярдів доларів у 1948 році до 2 трильйони доларів у 1986 році і до понад 6 трильйонів доларів у 2010 р. Однією з причин такого зростання $€$ роль глобального морського транспорту, на який припадає 70\% вартості обмінюваних товарів. Впродовж історії, i незважаючи на появу інших видів транспорту, морський транспорт залишається основою міжнародної торгівлі, при цьому контейнерні судноплавні лінії зростають від азіатських портів на схід до Північного Європейські порти на захід через Індійський океан, Аравійське море, Червоне море та Середземне море [1].

Наступні випадки показують прогресивну зміну стратегії в різних регіонах i портах щодо портової інфраструктури та послуги, які зазвичай надаватимуть державні установи/суб'єкти (уряд/регіони). Відбувся глобальний зсув у бік державно-приватного партнерства протягом останніх десятиліть із залученням приватного сектора, особливо в операційній діяльності та фінансуванні портової інфраструктури та послуг.

Критичними факторами успіху є всеосяжне та тверде бачення, тобто створення спільного бачення між державним сектором та всіма зацікавленими сторонами - це не завжди легко та також може бути проблематично в самому державному секторі. Зрештою, це повинно виходити із процесу досягнення консенсусу, який ретельно враховує можливості, цілі та загальні цілі громади. Бачення має включати чітку стратегію для впровадження, що означає механізми фінансування, чітко визначені обов'язки за потенційних партнерів, а також точний порядок денний або застосування часових рамок для завершення. 
Масштаб і ареал глибини слід оцінити якомога точніше, в т.ч для потенційного транзиту з сусідніми ринками та перевантаження через порти на короткі відстані, що може бути предметом виникнення суперечок.

Ринкові умови та демографічні показники також повинні бути ретельно проаналізовані, щоб переконатися, що бачення $€$ не надто вузьким, щоб задовольнити потреби громади, або занадто великий, щоб зіткнутися з фінансовими ризиками.

Розподіл ризиків. Центральний принцип розподілу ризиків полягає в тому, що кожен ризик має розподілятися на тих, хто може керувати ним найкраще. Управління розподіленими ризиками у приватному секторі покращує процес прогресу i завершення та збільшує показники успіху.

Проєкти ДПП у портах, як правило, це концесія, заснована на доходах, за якими приватна сторона сплачує, а плата (фіксована та залежна від обсягу) державному органу за право експлуатації порту.

Таким чином, приватний партнер бере на себе ризик попиту/доходу, який може бути пом'якшений, якщо $є$ гарантія мінімального доходу від контрактуючого органу. Оскільки угоди про ДПП $є$ довгостроковими та складними, контракти, як правило, створюють простір та можуть виникнути розбіжності в тлумаченні, і можуть виникнути суперечки. Визначення процесу вирішення спорів гарантує, що потенційні суперечки будуть вирішені швидко та ефективно, без перерв обслуговування. Механізми вирішення спорів можуть бути вбудовані в договір ДПП.

Відповідні процедури та правила це один із основних факторів успішного ДПП $€$ наявність правового режиму, заснованого на принципах прозорості, конкурентоспроможності та підзвітності. Адміністрація порту повинна відігравати вирішальну роль у встановленні правил, процедур і положень, які може вплинути на портовий сектор, а також дотримання практичних регуляторних процедур щодо того, що відбувається в рамках державно-приватного партнерства.

Точна реалізація проєкту. Спрощення та визначення тендерного процесу (в якому мають бути присутні всі зацікавлені сторони від залучених), чіткі визначення та процедури різних завдань, а також адміністративне схвалення від необхідної компетентності органів на різних етапах процесу реалізації проєкту у виконанні успішної програми ДПП.

Точна реалізація проєкту порту включає багато кроків: структурування та оцінка ДПП, розробка контракту ДПП, вибір партнерів, остаточні переговори та реалізація ДПП транзакція. Обов'язки кожного партнера, щоб уряд міг ефективно керувати контрактом, певними ролями та обов'язками необхідно чітко вимагати від приватного партнера. Уряд буде зберігати та переглядати його роль, можливо на різних рівнях, в управлінні контрактом. Він матиме стратегічний рекламний ролик роль управління контрактами в обміні політикою та іншими стратегічними розробками з приватними особами та партнерами.

Державний партнер зберігає сувору присутність і повноваження, шукаючи найкращі порти, що дозволяє всім зацікавленим сторонам знати свої точні обов'язки та зобов'язання, таким чином забезпечення безперебійного та ефективного партнерства між сторонами. Чіткий і справедливий тендерний процес. Як правило, приватна сторона ДПП 
обирається за допомогою публічного тендеру, враховуючи громадськість інтерес до такого конкурсу, що дає шанс усім залученим учасникам з досвідом і довірою до портових послуг та роботи. Тому тендерний процес $€$ добре структурованою основою для мінімізації витрат на тендер і стимулювання конкуренції.

Завершальним етапом є відбір і офіційний контракт, після чого можна приступати до укладання проєкту. Контроль і моніторинг. Щоб досягти максимальної вартості, обіцяної ДПП, уряд має забезпечити, щоб запланований розподіл відповідальності та ризиків втілювався в життя, контролювався, записуються, постійно аналізуються та перевіряються.

Моніторинг може здійснюватися різними способами та методами, наприклад дані, надані приватною стороною (дані про продуктивність відображаються в звичайному звіті) та додатково перевіряються незалежними експертами (шляхом перевірки стандартів обслуговування), та користувачів послуг (за допомогою процесів зворотного зв'язку, включаючи, наприклад, опитування щодо задоволеності).

Проєкт ДПП відрізняється від звичайного проєкту державного сектора, і його можна лише реалізувати через детальний і складний договір. Контракт має вирішальне значення для підтримки бізнесу відносини між державним і приватним секторами. Незважаючи на чіткий договір між обома сторонами, а ДПП все ще може перешкоджати багатьом питанням, які слід визначити та уникати для реалізації проєкту досягти успіху та досягти обох партнерів бажаних цілей [2].

Розширений (хоча й не вичерпний) перелік проблем, які можуть виникнути в ДПП:

Межі/кордони між державним і приватним секторами. Державна власність/власність на активи та функції з пріоритетом стратегічних питань, пов'язаних з національним суверенітетом. Державний сектор повинен відмовитися від своїх прав на майно та державне майно у приватному секторі до кінця концесії, коли вони будуть передані назад в уряд.

Державні послуги зазвичай керуються та надаються урядом; але в ДПП, приватний сектор надає державні послуги у спосіб, який відповідає цілям уряду цілі приватного партнера щодо отримання прибутку та вимоги певної форми компенсації за виконання обов'язків не отримують належної винагороди.

Баланс сил. Теоретично контракт повинен передбачати обмеження та забезпечувати рівноправність обох сторін ставки у відносинах. Насправді контракт може бути недостатньо розробленим для забезпечення балансу сил, який дозволить одній стороні перекласти ризики на іншу слабшу сторону, у цьому випадку може знадобитися для Арбітражного суду для узгодження.

ДПП в портах вимагають сильної політичної підтримки. У країнах, де порти грали в важливу роль в економіці, перехід від моделі публічного порту до моделі орендодавця може зустріти значну опозицію або призвести до напруженості між політичним контекстом та політика управління.

Підприємства можуть впливати на політиків, щоб гарантувати, що уряди виконають проєкт на основі ДПП, потім переукласти умови контракту протягом періоду концесії, якщо і коли це є виправданим. ДПП може надати приватному сектору доступ до державної та 
громадської інформації чиновників, дозволяючи тим самим лобіювати прибуткові ДПП, знаючи, що уряди та органи влади та операторипартнери не обов'язково переслідують ті самі цілі короткострокові (рентабельність) і середньострокові/довгострокові (подальший розвиток подій залежно від проблем, пов'язаних із портом).

Регулювання Структура (закон і контракти). Державно-приватні партнерства $€$ юридично складними 3 моменту їх впровадження та застосування торкаються кількох галузей права. Це може призвести до впровадження нового конкретного закону правила.

Орган/кваліфіковані особи. Навички, необхідні для оцінки та моніторингу ДПП, відрізняються від традиційних навичок державної служби. Успішне ДПП потребує досвідченого персоналу, у тому числі технічного персоналу для конкретної галузі навички та досвід у сфері регулювання, включаючи, можливо, навчання на високому рівні.

Область і поля. Контракт повинен враховувати та відображати обрану модель управління портом. Якщо для переходу на модель орендодавця необхідні налаштування та повноваження адміністрації порту, щоб забезпечити прозорість [3].

Координація (метод). Забезпечення ефективного процесу регулювання та координації для усунення регуляторних перешкод необхідним шляхом координації між урядовцями чи громадськістю та приватним сектором.

Моніторинг, аудит, оцінка. Неефективний моніторинг та оцінка може призвести до збільшення витрат на проєкт. Аудит проєктів ДПП відрізняється від діяльності державних структур. Пропаганда підзвітності, аудит не повинен перешкоджати залученню, інвестиціям та управлінню приватного сектора.

Крім питань контракту (наприклад, вплив, конкуренція). Складність контрактів ДПП може призвести до обмеженої участі в тендері, що надає перевагу антиконкурентної угоди серед небагатьох потенційних гравців. Крім того, ДПП може мати непрямий вплив на загальне економічне та соціальне середовище порту, включаючи зміни в традиційних практиках і необхідність перехідного періоду. Розгляд, подальше виконання висновків та рекомендацій. Враховуючи, що проєкти ДПП, а точніше проєкти ДПП портів, зазвичай $\epsilon$ довгостроковими та складними, контракти ДПП вимагають регулярного перегляду, щоб переконатися, що проєкт відповідає існуючим вимогам.

Використання на ДП «БМТП» антикорупційної програми встановлює певні стандарти та вимоги не нижчі, ніж передбачені Законом України «Про запобігання корупції». Антикорупційну програму затверджено рішенням (наказом) директора ДП «БМТП» після їі обговорення з працівниками і посадовими особами ДП «БМТП» [4].

Рекомендації щодо антикризового управління портом із використанням ДПП:

- вибір моделі ДПП слід ретельно виконувати відповідно до національних і регіональний контекст, особливості проєкту/порту, технічні та інституційні обмеження та ринкові умови;

- якщо концесійні угоди в портовому секторі $€$ обраним методом, то законодавча база для розвитку порту має бути налагоджено в кожній країні відповідно до її власних законів і нормативно-правових актів в транспортній сфері;

- кожна адміністрація порту повинна застосовувати чіткі та встановлені правила щодо тарифів, що накладаються на порти та 
користувачів терміналів. Розглядаючи питання про надання портових концесій чи укладання спільної угоди, портові органи повинні дивитися на фінансову діяльність підприємств, попередній досвід і репутація. Потенційні партнери ДПП повинні задовольняти будь-які фінансові та технічні стандарти що мають відповідні здібності та ефективність.

- термін ДПП має бути зазначений у договорі ДПП; у процедурах ДПП викладено різні види ДПП та договірний період для кожного. Крім того, договір ДПП повинен містити варіанти після закінчення концесійного договору (варіанти «виходу»): потрібно чи ні продовжити концесію, укласти концесію 3 іншою компанією або передати відповідальність уряду;

Висновки i перспективи подальших досліджень. Антикризове управління підприємством водного транспорту являє собою процес, основним змістом якого $€$ проведення підготовки, прийняття та процесу реалізації управлінських рішень щодо попередження виникнення криз, планування їх подолання та мінімізації виникнення негативних наслідків.

Відмінністю цього управління в порівнянні із багатьма іншими функціональними видами управління підприємством $€$ саме те, що в силу кризових явищ прийняття антикризових управлінських рішень часто відбувається в обстановці певного зниження керованості підприємством, дефіциту часу, високого ступеня невизначеності, різноманітності конфліктності інтересів різних груп робітників.

Для здійснення ефективного антикризового управління на ДП «БМТП» часто створюється спеціальна група висококваліфікованих менеджерів, наділяє особливими повноваженнями для прийняття та реалізації управлінських рішень.

References:

1. Bidenko K. R. Strategic environmental analysis of functioning of the enterprise as a anti-crisis management tool. Upravlinnia rozvytkom. №12. 2012. Pp. 107-109.

2. Hordiienko T. V. The anticrisis mechanism for measuring construction company performance. $2012 . \quad$ URL: http://archive.nbuv.gov.ua/portal/soc_gum/kgm_econ/2012_102/178187.pdf.

3. Ostrovs'ka O. A. Innovative instruments for crisis financial management of public enterprises. Aktual'ni problemy ekonomiky, № 9(123). 2011. Pp. 154-163.

4. Pererva P. H., Kosenko A. V. and Kosenko O. P. Anti-crisis tools for the sustainable development of the enterprise: innovation, investment and marketing policy. 2012 URL: http://www.nbuv.gov.ua/portal/natural/vcpi/TPtEV/2012 25/statti/16Per erv.pdf.

In this article, we analyzed the organizational mechanism of anticrisis port management based on the introduction of public-private partnership. In the current conditions of the pandemic, there is a need to support and improve the management mechanism of maritime and river transport enterprises. The development of the port, the maritime complex and the country depends on the application of a certain mechanism. 
The mechanism of anti-crisis management of the enterprise of the State Enterprise "BMTP" is proposed to be carried out in the following main stages. Carrying out of constant monitoring of financial activity of the enterprise for the purpose of fast and early detection of symptoms of crisis. In order to conduct monitoring is organized in the framework of general monitoring of the enterprise as an independent unit in order to identify early signs of a possible crisis.

At the first stage, a certain group of objects of observation is established in the system of general monitoring, which aim to form a possible so-called "crisis field" to determine the parameters of the financial condition of the enterprise, violation of which will tell us about crisis development. The second stage of the "crisis field" creates a system of observable indicators, the so-called "indicators of crisis development". The system of these indicators includes both traditional and special financial indicators that show various signs of pre-crisis state of the enterprise or the emergence of a crisis. At the third stage there is a certain periodicity of indicators of "indicators of crisis development". Usually, the indicators of this group are observed with the highest periodicity in the general system of financial monitoring. Moreover, in certain periods of high dynamics of external economic factors that threaten the crisis of the enterprise, the main of these indicators require daily monitoring and observation.

In the process of analysis, the degree of deviations that caused their causes is established, as well as the possible impact of such deviations on the final results of financial activities. At the sixth stage, according to the results of monitoring, a preliminary diagnosis of the state and nature of the development of financial activities of the State Enterprise "BMTP" and its financial condition is carried out. In the process of conducting such diagnostics, the "normal", "pre-crisis" or "crisis" state of the enterprise is determined.

The essence of anti-crisis management of the enterprise at this stage is noted as "management of weak signals" and has a predominantly preventive focus. There is an ability to realize the possibility of crisis prevention in the future dynamics of external and internal factors of the enterprise.

In the end, depending on the results of the assessment, the possible directions of action are differentiated, their focus on preventing the crisis or on mitigating the conditions of its future course. 